DOI:10.24193/tras.2017.0008

Published First Online: 2017/02/10
Abstract

Public administration is, especially in Eastern Europe, declaratively reformed to comply with European standards and trends. In order to define the mainstream topics and milestones of administrative development, a focused content analysis as a case study has been conducted with regard to Europeanization in 223 articles published between 2011 and 2014 in the leading specialized journals in Slovenia and Croatia (International Public Administration Review and the Croatian and Comparative Public Administration). The methodology of content analysis has been applied in order to gain objective and comparable results in the field and on the cross-national scale. The main findings reveal that Europeanization is the common thread in both journals and countries. However, based on the Slovenian and Croatian case study, one can claim that in Eastern Europe public administration is in earlier developmental stage, as countries are still often dealing with rather basic restructuring instead of upgrading of good administration principles as in the West. Moreover, the declared internationalization of public administration and best practices exchange are fragmented and underdeveloped. The Eastern European countries should consequently intensify their efforts to a more advanced and systemic understanding of the European standards to cope with modern challenges in our globalized society.

Keywords: public administration, content analysis, Europeanization, Eastern Europe, Slovenia, Croatia.

\section{DECLARATIONS AND REALITY OF EUROPEANIZED PUBLIC ADMINISTRATION IN EASTERN EUROPE: JOURNALS CONTENT ANALYSIS IN SLOVENIA AND CROATIA $^{*}$}

\section{Polonca KOVAČ Tina JUKIĆ}

\section{Polonca KOVAČ}

Associate Professor, PhD, Administrative Law Department, Faculty of Administration, University of Ljubljana, Ljubljana, Slovenia

Tel.: 00386-41-787.335

E-mail: polonca.kovac@fu.uni-lj.si

Tina JUKIĆ (corresponding author)

Assistant Professor, PhD, Organization and Informatics

Department, Faculty of Administration, University of Ljubljana,

Ljubljana, Slovenia

Tel.: 00386-15-808.543

E-mail: tina.jukic@fu.uni-lj.si

* This article is a revised version of the paper entitled 'Europeanization of Public Administration in Eastern Europe: Case Study of Slovenian and Croatian Specialized Journals', presented at the NISPAcee Conference, Zagreb, May 19-21, 2016. The NISPAcee contributions are not publicly available.

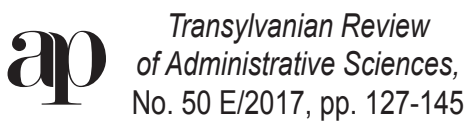




\section{Introduction}

Especially in Eastern Europe, due to its post-socialist development and globalized society and economy, the role of public administration (PA) is changing rapidly through recent years. It is largely directed at the Europeanization of the region that aspires to become an active part of the European Union (EU). In this context, we understand Europeanization as the introduction of the principles and standards of the European Administrative Space (EAS) and good administration into the regulation and the implementation thereof in national administrative systems. Consequently, the PA concept and trends in a certain environment indicate the overall political characteristics of a country and its regional setting.

Eastern European countries most often combine the Central European legal lega$\mathrm{cy}$, cope with transition-related issues, and are subject to EU requirements and processes, often complementary to their rather small size and hence lack of critical structures and administrative capacity. The same goes for Slovenia and Croatia which, before gaining independence in 1991, had been part of former Yugoslavia with state captured PA (namely between 1918 and 1941, and between 1945 and 1990). Even before that, the two countries had been sharing historical experiences, mostly following the Austrian and German trends of the Rechststaat ${ }^{1}$. A significant difference between them is that after 1991 there were only minor conflicts in Slovenia but a long-standing war in Croatia. Slovenia gained full membership of the EU in 2004, with Croatia following in 2013. As regards PA theory, the so-called Zagreb and Ljubljana schools on integrative PA and administrative sciences were relatively highly developed and recognized worldwide (Pusić, 2002, pp. 46-57; Koprić et al., 2014, p. 11). Institutes on PA were established first in Ljubljana in 1956 and later in Zagreb. Also, in 1956, the former Higher School of Administration was opened in Ljubljana, which in 2003 was transformed into the Faculty of Administration, running both BA and MA study programs accredited by the EAPPA. In Croatia, PA is studied mainly at the Faculty of Law in Zagreb and its autonomous chair on administrative science and through the institute of PA as established in 1997.

The research problem addressed in this article deals with the development of PA in Eastern Europe through the case studies of Slovenia and Croatia. The two countries report similar or even converging circumstances and results, but also significant differences and consequent delays regarding Europeanization in Croatia. The research follows Europeanization as a general key PA trend in the region, as indicated by the results of the content analysis (CA) of the two main PA related journals in the respective countries: the Slovenian International Public Administration Review

1 On regional PA traditions in Europe see Statskontoret (2005, pp. 74-76) and, in particular for Eastern Europe, Vintar et al. (2013), for Slovenia, Kovač (2013), and for Croatia, Koprić (2011) and Koprić, Musa and Lalić Novak (2012). Generally, see in Peters and Pierre (2003). See Raadschelders (2011, pp. 156-181) for Europe and the USA. On transition from Weber to New Public Management and other new models, see Mathis (2014, pp. 151-160). See also Kovač (2015, pp. 10-13). 
(Mednarodna revija za javno upravo, IPAR) published by the Faculty of Administration of the University of Ljubljana since 2003, and the Croatian and Comparative Public Administration (Hrvatska i komparativna javna uprava, CCPA) published by the Institute of PA, Faculty of Law of the University of Zagreb, and Novi informator since $1999^{2}$. Based on their uniqueness, we anticipate that these journals' mainstream topics reflect the actual PA development on the country level and in the main findings also for the broader region.

Slovenia and Croatia face severe difficulties, similarly to the whole Eastern Europe, such as politicized and too legally or formally oriented PA, only partially developed PA capacity to act within the EU and implement PA reforms, lack of coordination in PA and its transparency, etc. Some problems appear cross-nationally, while some are more evident in certain countries, but in general, there are gaps to be bridged in the future PA development in Eastern Europe as a whole (see Schimmelfennig and Sedelemeier, 2005; Dunn, Staronova and Pushkarev, 2006; Koprić, 2011, pp. 6-25; Koprić et al., 2014, pp. 319-344; Kovač, 2013, pp. 152-177). Therefore, a so-called formal democracy (Agh, 2013, p. 3) with some more in-depth results in certain (technical) areas is in place. Consequently, Slovenia and Croatia also had to adapt while preparing to become full members of the EU and still strive in practice for more developed EAS standards. We argue that today the European values are pursued through the Neo-Weberian State that prevails in the practice of PA and its theoretical development in Eastern Europe. On the other hand, there are system deficiencies in the PA in Eastern Europe which point to considerable gaps in its development and to the need for overcoming the presently mere declaratory statements. In this context, also the said PA journals in Slovenia and Croatia seem to focus on the problems and the solutions mentioned.

Following this concept, we address several research questions: What are the main topics recognized as the most important for Europeanization of Eastern Europe today? What are the key doctrinal governance issues emphasized in developing EAS in the region? Is PA still predominantly within the legal domain, as it traditionally used to be in the region, or is it evolving in an interdisciplinary direction? Is there convergence among the countries or can we identify crucial differences, such as in Slovenia and Croatia? The aim of the research is three-fold. First, we believe the topic in general is highly interesting for PA scholars throughout Europe, who seek to identify the most adequate governance modes. Second, data-based analyses such as this one can serve policy makers in broader Eastern Europe to design further reforms pursing Europeanization. Additionally, we find the results of the research useful for practitioners to verify their policies and conduct against Slovenian and Croatian examples.

2 More details on official webpages: http://www.fu.uni-lj.si/zalozba/mednarodna-revija-za-javnoupravo/ and http://www.iju.hr/HJU/o_casopisu.html. Both journals are referred by Worldwide Political Science Abstracts, CSA ProQuest, EBSCO Publishing, PA@BABEL, etc., with the IPAR submitting candidacy for Web of Science and Scopus as well in 2015. The IPAR and the CCPA are run by international editorial boards. 
This article is organized as follows. In the next chapter, the theoretical basis regarding the EAS as a framework for PA in Slovenia and Croatia is presented. In the following, the meta-analysis of previous approaches to PA CA is elaborated together with the methodology of our own CA of the two selected journals. In addition, the results of our research are presented and discussed. In conclusion, a final synthesis is given and areas for improvement identified.

\section{PA development in Eastern Europe through European Administrative Space and good administration}

Slovenia and Croatia belong to the same regional setting; above all as a part of Eastern European countries, hence they serve as an illustration of the respective region. It seems natural for both respective and other Eastern European countries to more or less bear the same historical legacy and post-1991 perceptions to move forward towards the European space. The latter has been set as a formal goal upon gaining full membership of the EU, but even more important are the actual dimensions of European oriented PA in real conduct and implementation phases. The EAS has served and still serves as a common European administrative infrastructure for the joint formulation and execution of public policy (Trondal and Peters, 2013, p. 295).

Both, formal and informal dimensions of Europeanization are addressed by the EAS. The first aspect is indicated in the horizontal criteria for EU membership, including the PA expressing capacity to implement the acquis communautaire. However, EAS is especially important when there is a question of informal and in-depth understanding of the European standards, since EAS is after all about the implementation of the principles. The main formal framework supporting Europeanization in Eastern Europe is SIGMA - a joint venture of the OECD and the EU. SIGMA papers define the main principles of EAS as follows: (1) rule of law with reliability, predictability and legal certainty; (2) openness and transparency, based on consistency; (3) accountability, in connection to pursuing lawful actions; and (4) efficiency in use of public resources and effectiveness in accomplishing the goals established in legislation (see OECD, 1998, pp. 112-116; Cardona Peretó and Freibert, 2007, p. 53; Koprić et al., 2014, pp. 320-324; OECD, 2014).

The main goals with regard to PA are mostly related to its professionalism, enhanced capacity and coordinated systems actions, and other issues regarding civil service (Cardona Peretó and Freibert, 2007, p. 57). There are also issues, specifically emphasized, such as good administration in administrative procedures, participation, agencies, e-government, public expenditure, etc. and individual sector-specific policies (e.g., protection of consumers, customs, environment). On the other hand, the EU pursues no specific governance model or PA organization. However, there is the 'obligation of results' to achieve a homogeneous conduct of PA across the EU in relation to citizens and other users of public services (Cardona Peretó and Freibert, 2007, p. 52; more in D'Orta, 2003). It is about convergences and integrated administration in actions or the so-called 'shared sovereignty' (as defined by Hofmann, 2008). 
The aim of PA reforms within the EAS was and still is (Kovač, 2003) that their effects to be based and lead to common European values and principles regardless of an individual country's legal order, its authority structure or certain PA measures.

However, EAS development has been rather inconsistent and fluid despite initial ambitious system approach prospects (see Olsen, 2003; D'Orta, 2003; Hofmann, 2008). The need for harmonization with EU law further contributes to convergence, but the efficiency of national administrative systems varies (Kovač, 2013; Koprić et al., 2014, p. 325 , etc.). Consequently, it is nowadays only taken as partial reference or evolving into other concepts ${ }^{3}$. Most important for the candidate countries seem the 'Principles of PA' (OECD, 2014). Thus, the EAS, highly recognized and understood in the beginning of this millennium, has been largely replaced by the good governance and good administration doctrines (Kovač, 2015, p. 12; Koprić, Musa and Lalić Novak, 2012; see also 'Code of Good Administrative Behaviour' as adopted by the European Ombudsman in 2001, 2004, and 2012, and article 41 of the 'Charter of Fundamental Rights of the EU', 2010). However, the latter pursues practically the same values, principles, approaches and perceived results, so it is more about the title than about the content. The notion of good administration is most often found in legal theory, particularly since the European Court of Justice has developed the basic principles of administrative law through its case law. Nevertheless, it is considered here in a broader sense as democratic and efficient designing and implementation of public policies. In other words, the actual point of good administration within the EAS for PA is to act proactively and synergistically on national and European levels alike.

To sum up, we understand the EAS or the Europeanization of PA toward 'good administration', as present in administrative sciences through the IPAR and the CCPA articles, in a broader sense. Whenever there is any reference to joint EU administrative principles, we see Europeanization as an emerging topic. However, to highlight the real effect, we distinguish in the following CA between rather basic or 'hard', i.e., more formal, narrowly oriented and monodisciplinary EAS elements, and 'soft', more fine-tuned, systemic and interdisciplinary principles. The first include formal reforms and their consistency and PA stability, (de)centralization of authority and its structures, and basic standards on public finances. The latter comprise more

3 On partial reference, for instance regarding regional cooperation, see Beck (2015). Beck also refers to other authors, recognizing EAS development in several phases of integration on EU level: firstly values, then institutional cooperation, thirdly legal harmonization (Hofmann, 2008, pp. $662,671)$ and lastly multilevel EU governance. Hence, development has been initially directed to transculturalization but is today rather evolved as hybridization (Beck, 2015, p. 11). Similarly see Pusić (2002, pp. 53-59) who analyses the emergence of integrative interdisciplinary administrative science, but in parallel, in time and space, also disintegration and differentiation. Generally see Trondal and Peters (2013) who argue that the process of institutionalization within the EAS indicates three dimensions: independence, integration and co-optation of PAs. They continue that 'EAS I' therefore represents initial convergences of administrative systems, but 'EAS II' stands for development of new institutional constellations and configurations. 
ambitious principles, such as the rule of law and protection of human rights, transparency and participation, good administration with e-government and modernization of administrative procedures, and efficient and effective management of human and other resources in PA (HRM; and Total Quality Management, TQM). These topics directly correspond to the above stated EAS principles. Such distinction and stages correspond further to the development in the EU (see Cardona Peretó and Freibert, 2007 p. 56; Trondal and Peters, 2013, p. 297; Agh, 2013, p. 11).

\section{Analysis of the Slovenian IPAR and the CCPA - methodological and contextual issues}

\subsection{Previous content analysis of $P A$ research}

CA has recently become an acknowledged method within social research and PA in particular. The intention of some CAs is to identify the characteristics of PA research in a specific region, others tend to evaluate the methodological aspects of PA research in great detail, while most of them try to categorize the papers in pre-defined topics that constitute the PA discipline. In general, previous PA CAs analyzed three categories of parameters: (1) authorship-related characteristics (e.g., affiliation and collaboration), (2) methods employed in PA research, and (3) topical orientation (and other parameters, see Perry and Kraemer, 1986).

When it comes to topical orientation identified within previous CAs in the field of PA, one can easily notice that almost every author developed his/her own classification of topics (varying from 10 to 30 topics). This makes comparison or meta-analysis much harder. Table 1 presents the topics that were most frequently the subject of research. Even though the classification of topics differs greatly among the authors of previous CAs, it can be noted that some topics appear more than once on the top three list, namely (1) administrative theory, (2) (new) public management and related reforms, (3) human resources and public policies. Other topics that gained considerable attention in the PA research include education, budgeting, local self-government, social and environmental policies.

Table 1: The most discussed subjects in previous PA CAs research

\begin{tabular}{ll}
\hline \multicolumn{1}{c}{ Authors } & \multicolumn{1}{c}{ Subjects } \\
\hline Perry and Kraemer (1986) & - Administrative theory \\
& - Public management \\
- Gublic policy & - Public managent and organizational behavior \\
- Human resources \\
- Public management \\
- Comparative/international research \\
- Special reports/PAR report \\
- Administrative theory \\
- Public management \\
Cheng and Lu (2009)
\end{tabular}




\begin{tabular}{ll}
\hline \multicolumn{1}{c}{ Authors } & \multicolumn{1}{c}{ Subjects } \\
\hline Lopižić (2013) & - New public management \\
& - Way of work \\
- Local and regional self-government & Public policy theories and concepts \\
Tung-Wen Sun and Yu-Wen Lin (2013) & - Public organization management \\
& - New public management \\
& - Management reform \\
Walker, Brewer and Choi (2014) & - Social policy \\
& - Reform \\
Henderson and Terry (2014) & - Education/Training/Teaching/Pedagogy \\
& - Budgeting/Public finance \\
\hline
\end{tabular}

Source: Authors' research

\subsection{Hypotheses and methodology of CA of the IPAR and the CCPA}

CA is rather unused in our region, so we applied it to gain new and original insights. Slovenia and Croatia were taken as case study countries for the whole of Eastern Europe due to their commonalities and differences in terms of their PA development and EU related progress. In order to explore to which extent PA research and development in Slovenia and Croatia relates to the EAS, 223 articles were analyzed (78 or $35 \%$ published in the IPAR and 145 or $65 \%$ in the CCPA, see Table 2). The period between 2011 and 2014 was selected to identify the existing elements and detect trends and potential differences in any of the journals or countries analyzed within this period. Our research incorporates particularly analyses of the mainstream topics (to get comparative insight regarding results of analyses from West and East as indicated in Table 1), the discipline orientation, methodology, comparisons especially in the EU context, language, the authors' origins and affiliation.

Table 2: Scope of the CA in the IPAR and the CCPA

\begin{tabular}{|c|c|c|c|c|c|c|}
\hline & 2011 & 2012 & 2013 & 2014 & Sum & Average* \\
\hline IPAR sum & 19 & 20 & 18 & 21 & 78 & $\begin{array}{l}19.5 / \text { year } \\
4.9 / \text { issue }\end{array}$ \\
\hline CCPA sum & 34 & 42 & 37 & 32 & 145 & $\begin{array}{r}\text { 36.3/year } \\
\text { 9/issue }\end{array}$ \\
\hline IPAR scientific papers: 1.01-03 & 13 & 13 & 12 & 17 & 55 & $\begin{array}{r}3.4 / \text { issue } \\
70.5 \% \text { of all }\end{array}$ \\
\hline CCPA scientific papers: 1.01-03 & 29 & 35 & 35 & 30 & 129 & $\begin{array}{l}8.1 / \text { issue } \\
89 \% \text { of all }\end{array}$ \\
\hline
\end{tabular}

*Both journals publish regularly four issues annually (the IPAR with double issues in 2013 and 2014).

Based on theoretical and developmental grounds (see sections 1 and 2 of this paper) and above preliminary overview, we formulated two main hypotheses (H1 and H2) to be verified:

H1: PA in both Slovenia and Croatia is set within a European and EAS context.

- H1.1: The mainstream topics in the IPAR and the CCPA between 2011 and 2014, namely in Slovenia and Croatia, are convergent regarding their international/European focus. 
- H1.2: Convergence is characteristic also in terms of the topics' interdisciplinary content and the mixed (advanced and quantitative included) PA related methods applied.

H2: There are some divergences between Slovenia and Croatia, but mostly in terms of time scale with Slovenian PA research preceding the Croatian one as regards more demanding EAS elements.

- H2.1: There are more articles in the IPAR on implicit European principles, i.e., good administration (human rights, participation, and procedures) and management, and less on PA reforms, organization and finances compared to the CCPA between 2011 and 2014.

- H2.2: There are more articles in the IPAR that reflect an international approach, i.e., broader scope, comparisons, authors' international cooperation and foreign language used, compared to the CCPA.

To verify these sub/elements, we formulated a codebook (see Appendix) on the elements gathered and analyzed in CA through Excel. The following characteristics were elaborated:

- Descriptive characteristics: year of publication, title, typology, language, authors' affiliations, nature of collaboration based on institution origins, international collaboration among co-authors;

- Dominant disciplines and topical orientation; ; and

- Geographical focus of the paper, comparative and particularly EU related dimension of the research.

Both authors conducted the CA separately and only afterwards the results were compared, the possible differences discussed and settled to reach consensus. Such a method contributed to the objectivity of the results since the profiles of authors are different in terms of expertise and experiences. The accomplished agreement proved a result to be sufficiently legitimate.

\section{Research findings and discussion upon PA development in Eastern Europe}

\subsection{Topical and disciplinary orientation: convergences and differences}

Given the many common characteristics of the Eastern European region as a whole and of Slovenia and Croatia in particular, we assumed there would be similarities also in terms of the focus of PA reforms and Europeanization trends. Elements of conver-

4 As PA 'mother disciplines', law, economics and management, policy analysis, and informatics are considered (Schuppert, 2000, p. 45; Raadschelders, 2011, p. 30). We additionally identified 'individual policies/fields' (such as education, customs, social policy, consumers, etc.), since these papers address this topic always multi- if not interdisciplinarily. We paid special attention to the list of disciplines, and further topics to classify them so as to avoid double categorization, since we established that most researchers mix them by listing side by side topics and horizontally the disciplines (see Table 1, e.g., Bingham and Bowen, 1994, p. 205). 
gence were pursued by hypothesis 1 , especially as regards mainstream topics within the European context and their interdisciplinary elaboration. In order to explore both dimensions, i.e., the disciplinary and the topical one, we developed a model of $2 \times 2$ (Kovač and Jukić, 2016). First, we identified each paper from two points of view, a disciplinary and a topical one. Then, we defined the second dominant discipline and topic of each article, if applicable, to follow the principle of a more interdisciplinary approach in case of the most relevant disciplines and topics. The two dimensions are important considering the initially emphasized nature of research in the field of PA, since PA as a discipline needs to address PA phenomena scientifically and interdisciplinarily in order to successfully resolve the respective complex problems (Bevir, 2011, p. 374; Kovač, 2015, p. 16). Given the historical and regional characteristics of Eastern Europe, legally and lately managerially determined topics were expected. The topics that in fact emerged as the most frequent are the following (see Table 3): in Slovenia: (1) public finances, (2) HRM, (3) individual policies, (4) processes and good administration, (5) TQM; and in Croatia similarly, but above all: (1) regionalism, (2) PA organization and reforms.

Table 3: Dominant topics in PA research in Slovenia (IPAR) and Croatia (CCPA)

\begin{tabular}{|c|c|c|c|c|c|c|c|c|}
\hline \multirow[b]{3}{*}{ Note: $\%$ are rounded. } & \multicolumn{4}{|c|}{$1^{\text {st dominant topic }}$} & \multicolumn{4}{|c|}{$2^{\text {nd }}$ dominant topic } \\
\hline & \multicolumn{2}{|c|}{ IPAR } & \multicolumn{2}{|c|}{ CCPA } & \multicolumn{2}{|c|}{ IPAR } & \multicolumn{2}{|c|}{ CCPA } \\
\hline & $\mathrm{n}$ & $\%$ & $\mathrm{n}$ & $\%$ & $\mathrm{n}$ & $\%$ & $\mathrm{n}$ & $\%$ \\
\hline Human rights & 3 & 4 & 4 & 3 & 1 & 1 & 8 & 6 \\
\hline Regulation of PA, better regulation & 7 & 9 & 7 & 5 & 3 & 4 & 7 & \\
\hline Transparency, openness, participation, civil society & 3 & 4 & 6 & 4 & 0 & 0 & 6 & 4 \\
\hline Organization in PA, state bodies, decentralization, agencies & 4 & 5 & 8 & 6 & 6 & 8 & 24 & 17 \\
\hline Regionalism, local self-government & 2 & 3 & 44 & 30 & 8 & 10 & 5 & 3 \\
\hline HRM, civil service, ethics, integrity & 11 & 14 & 13 & 9 & 9 & 12 & 6 & 4 \\
\hline Public finances, budget, taxes & 16 & 21 & 7 & 5 & 4 & 5 & 11 & 8 \\
\hline E-government & 5 & 6 & 0 & 0 & 0 & 0 & 1 & 1 \\
\hline TQM, NPM, good governance & 9 & 12 & 4 & 3 & 2 & 3 & 10 & 7 \\
\hline Privatization, public services/conc & 2 & 3 & 7 & 5 & 1 & 1 & 4 & 3 \\
\hline Processes, administrative procedures and acts, good administration & 7 & 9 & 13 & 9 & 8 & 10 & 12 & 8 \\
\hline Individual public / PA policies & 8 & 10 & 14 & 10 & 16 & 21 & 13 & 9 \\
\hline PA / PS (general) reform/s & 0 & 0 & 13 & 9 & 1 & 1 & & 5 \\
\hline PA discipline/administrative science & 1 & 1 & 5 & 3 & 1 & 1 & 5 & 3 \\
\hline None & 1 & 1 & 1 & 1 & 18 & 23 & 26 & 18 \\
\hline Sum & 78 & 100 & 145 & 100 & 78 & 100 & 145 & 100 \\
\hline
\end{tabular}

As perceived by H1.1 and H2.1, there are some convergences since in both countries transitional issues in PA in general and in individual public policies seem to be important. A further commonality is found when comparing the most emphasized topics addressed in the majority of other journals analyzed by CA (Terry, 2005, p. 644; Bingham and Bowen, 1994, p. 206; Lopižić, 2013) to the IPAR and the CCPA issues. We believe that such convergences, although sometimes considered as mere window dressing for or forced by the EU (Koprić et al., 2014, p. 326), inevitably demonstrate the globalization of PA due to contemporary changes in the society in terms of cross-national processes, delegation of powers outside national state administrations, 
privatization, etc. In this respect, we can confirm our hypothesis 1.1 stating that there are certain general topics relevant in the region as joint trends since the EAS represents global principles of contemporary PA and public governance, striving for an efficient yet democratic political-administrative system.

On the other hand, certain topical divergences are immediately detected as well. Considering the apparently different list of recurrent themes and their prioritization, we confirm our hypothesis 2.1, presuming that there are differences between countries that are ahead with their process of Europeanization and those taking slower steps. Namely, Slovenia - as one of first Eastern European countries to fulfil the EU criteria (Kovač, 2013; Agh, 2013) - has recently devoted attention in PA development to more complex topics, such as principles of good administration, openness, participation and accountability, and managerial issues, compared to more basic themes of PAR and PA organization and finances. Summing up all shares of papers in the IPAR regarding the first set of topics, one notes that $51 \%$ of papers deal with such topics as the first dominant topic, compared to only $28 \%$ in the CCPA. Furthermore, the CCPA includes $50 \%$ of papers addressing more formal and basic topics of reorganization and PAR as the first dominant orientation, compared to only $29 \%$ in the IPAR. These figures reveal significant differences in both directions that consequently led us to verify $\mathrm{H} 1$ in both sub-elements. However, any such complex process as PA Europeanization requires a step-by-step approach. We must learn to walk before we can run, which is a lesson to be learned by policy makers in Eastern Europe to avoid the generally identified implementation gap and low administrative capacity (Dunn, Staronova and Pushkarev, 2006; Koprić, 2011; Kovač, 2013; Kovač, 2015).

Both dimensions of $\mathrm{H} 1$ were further verified through disciplinary elaboration since individual policies - being among the most common topics in both countries - are inevitably dealt with in an interdisciplinary manner. They account for one fifth of all cases in Croatia and for one third in Slovenia (Table 4). On the other hand, both countries address law quite often, but Croatia apparently more strongly, with 50\% of papers in this field compared to $35 \%$ in Slovenia. However, there is an important difference in terms of policy perspective addressed by Croatia in $44 \%$ of the papers compared to the low Slovenian share of $14 \%$. Economics and management prevail in

Table 4: Dominant disciplines in PA research in Slovenia (IPAR) and Croatia (CCPA)

\begin{tabular}{|c|c|c|c|c|c|c|c|c|}
\hline \multirow[b]{3}{*}{ Note: $\%$ are rounded. } & \multicolumn{4}{|c|}{$1^{\text {st }}$ dominant discipline } & \multicolumn{4}{|c|}{$2^{\text {nd }}$ dominant discipline } \\
\hline & \multicolumn{2}{|c|}{ IPAR } & \multicolumn{2}{|c|}{ CCPA } & \multicolumn{2}{|c|}{ IPAR } & \multicolumn{2}{|c|}{ CCPA } \\
\hline & $\mathrm{n}$ & $\%$ & $n$ & $\%$ & $\mathrm{n}$ & $\%$ & $\mathrm{n}$ & $\%$ \\
\hline Law & 20 & $26 \%$ & 42 & $29 \%$ & 7 & $9 \%$ & 31 & $21 \%$ \\
\hline Economics & 20 & $26 \%$ & 11 & $8 \%$ & 3 & $4 \%$ & 6 & $4 \%$ \\
\hline Management & 18 & $23 \%$ & 28 & $19 \%$ & 7 & $9 \%$ & 6 & $4 \%$ \\
\hline Politology/policy/sociology & 8 & $10 \%$ & 50 & $34 \%$ & 3 & $4 \%$ & 15 & $10 \%$ \\
\hline Informatics & 5 & $6 \%$ & 0 & $0 \%$ & 2 & $3 \%$ & 1 & $1 \%$ \\
\hline Individual fields/interdisciplinary & 7 & $9 \%$ & 14 & $10 \%$ & 17 & $22 \%$ & 13 & $9 \%$ \\
\hline None & 1 & 1 & I & 1 & 39 & $50 \%$ & 73 & $50 \%$ \\
\hline Sum & 78 & $100 \%$ & 145 & $100 \%$ & 78 & $100 \%$ & 145 & $100 \%$ \\
\hline
\end{tabular}


Slovenia, with $62 \%$ as the first and the second dominant disciplines, opposed to only $28 \%$ in Croatia.

We see that $23 \%$ of the papers are rather monodisciplinary in Slovenia, while this share is still very high in Croatia with $44 \%$. Despite the differences, we conclude for both cases that the monodisciplinary approach and the lack of other disciplines, such as politology in Slovenia and informatics in both countries, result in a gap that needs to be bridged. Modern PA requires global, but above all an interdisciplinary approach to resolve the so-called 'wicked issues of public governance' (Raadschelders, 2011, pp. 12-41). In sum, the IPAR and the CCPA CA proves that the Slovenian and Croatian PA and research are still mostly asymmetric and multidisciplinary, as well as fragmented or in the phase of EAS I of (continuing) building up formally joint values, laws and policies (Trondal and Peters, 2013; Hofmann, 2008, p. 663); although Slovenia is more progressively bridging the gap. This is common to both Eastern Europe countries and to the majority of other national PAs (e.g., in Germany or in the Netherlands (Benz, 2005, p. 662; Noordegraaf, Brandsen and Huitema, 2006, p. 1000)). Scholars and policy makers should in this sense support the systemic efforts of individual countries towards gradual development (Cardona Peretó and Freibert, 2007; Hofmann, 2008). Nevertheless, after completing a certain stage, such as acquisition of formal EU membership, the countries should continue with more demanding mainstream topics and progressive PARs in order to develop advanced participatory democracy and (more) efficient administrative structures.

In order to verify the assumed convergences at least on a regional level (H1.2), we further analyzed the methodological issues of PA research. We estimated as highly developed the methods that reflect the interdisciplinary nature of PA, namely applying complementary normative and empirical, qualitative and quantitative methods. Regarding the methods employed in Slovenia and Croatia, analysis revealed that quantitative research methods are used according to the presumption of further developed PA more frequently in the IPAR (35\%) than in the CCPA $(25 \%)$. Among the most often applied qualitative methods we find reviews of reports and strategies ( $80 \%$ in the CCPA and $51 \%$ in the IPAR), legislation (73\% in the CCPA and $53 \%$ in the IPAR), and literature (68\% in the CCPA and 55\% in the IPAR) - but no rather sophisticated methods as characteristic for instance in Anglo-Saxon environment. Furthermore, in the CCPA papers based on qualitative methods, authors more frequently employ three $(41 \%)$ or even four $(26 \%)$ different qualitative methods, while in the IPAR two such methods per paper prevail (41\%). Only one qualitative method is detected in the IPAR in $24 \%$ and in the CCPA in $8 \%$ of the cases, which, especially in the latter case, is positive in terms of interdisciplinarity since more methods imply a more complex research approach and the results are more representative ${ }^{5}$. Contrary - even

5 These results partially contradict the former findings on a more comprehensive PA in Slovenia (Kovač and Jukić, 2016) since the CCPA seems to offer a more advanced methodology. We believe this is a result of an atypical yet presently high level of monodisciplinary economics-related 
though the usage of quantitative methods was not analyzed in full detail - it should be noted that in most cases, in both journals and countries, the quantitative methods applied mainly cover simple descriptive statistics indicating a room for improvement in terms of more sophisticated data analysis techniques as characteristic of PA worldwide. In the future, more advanced and complementary methods are to be applied in order to develop PA as an autonomous scientific discipline (Pusić, 2002, p. 46; Raadschelders, 2011, pp. 4-12) and a base for better public governance.

\subsection{Convergences and divergences \\ in the level of Europeanization and internationalization}

Regarding our core research questions on the topical orientation of papers in the IPAR and the CCPA, which we presume to be more related to the EAS over time, we further verified H2.2 concerning the international scope of papers and cross-national cooperation of authors. We assumed to identify within our CA a higher level of internationalization in Slovenia due to its longer Europeanization process. The indicators that we followed in this respect were: 1. (broader) geographical focus of the paper and its Europeanization; 2. identified comparability of the topics addressed, presuming that regional and EU-related comparisons express the earlier EAS-related approach (Table 5); 3. nature of collaboration according to co-authors' affiliation, presuming that more diversified cooperation leads to higher interdisciplinarity (Table 6); and 4. (more) foreign language used.

There is in both journals the geographical focus present only on one country in the highest proportion ( $92 \%$ in the CCPA and $87 \%$ in the IPAR). The IPAR papers cover 30 different countries or regions, while the CCPA papers focus on 43 countries and regions. Within the IPAR, the top five discussed countries/regions are Slovenia (38 papers), EU (12), Germany (7), Croatia (6), and Sweden (5). In sum, these countries were observed 68 times. In the CCPA, the most popular geographical areas of focus are Croatia (63 papers), Slovenia (21), France (12), Serbia (11), EU, and Bosnia and Herzegovina (7 each); in sum, these countries were analyzed 120 times. However, when assessing the Europeanization dimension, and the EAS and good administration specifically, only less than half of all papers are EU-related. As regards the EAS, there is not even one single article found in the IPAR, while there are 15 or $10 \%$ of all CCPA papers that can be categorized in this group 6 . We can conclude that Slovenia sees no need for consideration of the EAS principles anymore, while harmonization is still present in Croatia, having been a member of the EU for only two years. On the

topics in the IPAR that should be verified over a longer period of time and larger sample of papers.

6 The titles of the respective articles are, for instance: 'The European Administrative Space as a Challenge for PA Reform'; 'Strategy of Administrative Reform in the Context of European Integration'; 'The Quality of Governance in PA Reforms in New Democracies'; 'Europeanization of PA in Eastern and Central Europe'. 
other hand, we argue that in the case of countries like Slovenia, there is still considerable room for improvement since mainly formal conditions are fulfilled with gaps of full capacity evident in many areas, such as inter alia institutional cooperation, regulation, efficient procedures, servants' capacity.

The comparative method indicates, as presumed, the strive for a broader disciplinary and geographically set scope of research. Yet, despite both journals' declaratory orientation toward internationalization and interdisciplinarity observed in as much as $41 \%$ of the articles in the IPAR and $26 \%$ in the CCPA, no comparison was used (Table 5). This result might come as a surprise but we believe the reason for this is the same as explained above in relation to the (non) Europeanization of the papers which, if not carefully managed, leads to an implementation gap even in presumably more developed countries. The same goes for the ratio between individual country and EU-related papers: $26 \%$ in the CCPA compared to only $4 \%$ in the IPAR.

Table 5: Comparative research of the papers in the IPAR and the CCPA 2011-2014

\begin{tabular}{|l|c|c|c|c|}
\hline \multirow{2}{*}{ Note: $\%$ are rounded. } & \multicolumn{2}{|c|}{ IPAR } & \multicolumn{2}{c|}{ CCPA } \\
\cline { 2 - 7 } & $\mathrm{n}$ & $\%$ & $\mathrm{n}$ & $\%$ \\
\hline No & 32 & 41 & 37 & $\mathbf{2 6}$ \\
\hline Yes, comparison among countries & 23 & 29 & 33 & 23 \\
\hline Yes, countrylies vs. EU & 3 & 4 & 38 & 26 \\
\hline Yes, comparison among organizations & 17 & 22 & 26 & 18 \\
\hline Yes, time-based comparison & 3 & 4 & 11 & 8 \\
\hline Sum & $\mathbf{7 8}$ & $\mathbf{1 0 0}$ & $\mathbf{1 4 5}$ & $\mathbf{1 0 0}$ \\
\hline
\end{tabular}

As regards collaboration in research and authorship (Table 6), such is rather low and in some aspects even non-existing. Most surprisingly, the majority $(87 \%)$ of the papers in the IPAR in 2011-2014 do not reflect international collaboration, while the proportion in the CCPA is even a $100 \%$. Furthermore, among the papers written by two or more authors, indicating a potential international orientation, collaboration was observed mainly within the same university or even faculty, but in significantly higher share in Croatia (63\%) than in Slovenia (32\%). Even if we add students' collaboration as observed in the IPAR, the share of $58 \%$ without external relations is questionable.

Table 6: Co-authors' affiliation in the IPAR and the CCPA 2011-2014

\begin{tabular}{|l|c|c|c|c|}
\hline \multirow{2}{*}{ Nature of collaboration } & \multicolumn{2}{|c|}{ IPAR } & \multicolumn{2}{c|}{ CCPA } \\
\cline { 2 - 6 } & $\mathrm{n}$ & $\%$ & $\mathrm{n}$ & $\%$ \\
\hline Faculty/research institute vs. faculty/institute = same organization & $\mathbf{1 2}$ & $\mathbf{3 2}$ & $\mathbf{1 9}$ & $\mathbf{6 3}$ \\
\hline Faculty/institute vs. faculty/institute = different & 10 & $\mathbf{2 6}$ & 5 & 17 \\
\hline Faculty (professor) vs. graduate/student & 10 & $\mathbf{2 6}$ & 0 & 0 \\
\hline Faculty vs. public sector/civil servant or NGO & 3 & 8 & 4 & 13 \\
\hline Faculty vs. international organization & 1 & 3 & 0 & 0 \\
\hline Other (e.g., faculty and private organization) & 2 & 5 & 2 & 7 \\
\hline Sum & $\mathbf{3 8}$ & $\mathbf{1 0 0}$ & $\mathbf{3 0}$ & $\mathbf{1 0 0}$ \\
\hline
\end{tabular}

When comparing the results of this CA to previous CAs in PA, further convergences can be observed. Globally speaking, the USA or Asia included, scholars are 
almost exclusively single authors, researching their own or one neighboring country only (Chen and Lu, 2009; Walker, Brewer and Choi, 2013; Henderson and Terry, 2014). As regards methodology, these papers are - considering the interdisciplinary nature of PA - underdeveloped, even though the situation is improving over time (Perry and Kramer, 1986; Lee, Benoit-Bryan and Johnson, 2009).

On the contrary, stronger internationalization in Eastern Europe is evident in the use of foreign language, with $78 \%$ of articles in the IPAR and $52 \%$ in the CCPA in English (as opposed to $43 \%$ in the CCPA and $21 \%$ in the IPAR with articles only in domestic language). English is nowadays apparently lingua franca, generally and in PA research in Eastern Europe as well. We strongly believe, based on globalized PA trends, that especially scholars in Eastern Europe should make the effort to prepare and disseminate their research results also in a foreign language. In fact, Eastern European countries are often small, so the use of English can significantly enhance their voice on the European level.

\section{Conclusions}

As any complex system, PA is evolving over time. The contemporary society requires good administration in the sense of implementation of the EAS principles, but beyond the formal adoption of PAR strategies and new laws. The latter problem is present especially in Eastern Europe, with gaps due to the ongoing post-socialist transition, the lack of administrative capacity, and gradual but inconsistent reforms. In order to support a systemic approach, we analyzed convergent trends emerging in Slovenia and Croatia, chosen as case studies of European countries, both members of the EU (Slovenia since 2004 and Croatia since 2013). As expected, we established many convergences regarding the overall Europeanization, as well as certain systemic gaps and divergences due to different stages of development within the EAS between the two countries. We assumed and mainly confirmed the backlogs and divergences to be due to the war in Croatia (1991-1995), as well as to difficult economic and political issues that hindered democratization (see Koprić, 2011, on rather low international positions of Croatia according to the rule of law or corruption perception or doing business indicators; for broader insight see Agh, 2013). Croatia (and similar countries) should have resolved these external and internal problems before joining the EU. This difference between the two (Eastern European groups of) countries is evident also in the IPAR and the CCPA, where Slovenia puts greater focus on European themes and international cooperation. Developing PA by scientific methods and publication therefore plays a key role in both types of countries in Eastern Europe.

To answer the initial research questions of this paper, we confirmed that there are several mainstream topics characteristic of contemporary PA in the European and wider context, regardless of the administrative tradition and region. This is important since PA is a globalizing system. On the other hand, some themes appear to be emerging more evidently in Eastern Europe, as the administrative capacity and PA research are still underdeveloped. PA in Eastern Europe is hardly and definitely not 
sufficiently interdisciplinary to face the complex problems of today's governance. In this sense, all PA-related disciplines are important and need to be taken into account, not solely law and politology or economics and management. This region presents only slow progress from the traditional legalistic platforms to the contemporary principles of good governance. In several cases, attempts are being made to replace the traditional legal approach with managerial or policy related ones, but these attempts remain rather formal and not fully embedded in the PA function. We believe that the right way to achieve results is to acknowledge where we stand, and to pursue reforms realistically but consistently, from formal and hard issues to complex and soft principles - which of course takes decades but seems to be worth it for the welfare of us all.

To conclude, despite a general converging trend in PA, individual countries in Eastern Europe proceed forward more or less rapidly, depending on their formal Europeanization process and broader political-administrative characteristics. Hence, the topical and disciplinary orientation varies. Countries and regions that are ahead in the Europeanization process usually address more complex issues related to the principles of good administration, participation, and management, while others still or firstly focus on PA general reforms, reorganization, regionalism, and public finances. However, given the growingly complex and global nature of contemporary societal and thus PA problems, these characteristics seem too narrow for contemporary PA and synthetization of new governance models. This task remains unrealized so far but inevitable in the future.

\section{References:}

1. Agh, A., 'Europeanization of Public Administration in the ECE: The Challenge of Participative Democracy and Good Governance', 2013, IPSA (RC 32) 2013 Conference, Dubrovnik: CAAS.

2. Beck, J., 'Cross-Border Cooperation and the European Administrative Space - Prospects from the Principle of Mutual Recognition', 2015, International Public Administration Review, vol. 13, no. 2, pp. 9-36.

3. Benz, A., 'Public Administrative Science in Germany: Problems and Prospects of a Composite Discipline', 2005, Public Administration, vol. 83, no. 3, pp. 659-668.

4. Bevir, M. (ed.), The SAGE Handbook of Governance, London: Sage, 2011.

5. Bingham, R.D. and Bowen, W.M., " "Mainstream” Public Administration over Time: A Topical Content Analysis of Public Administration Review', 1994, Public Administration Review, vol. 54, no. 2, pp. 204-208.

6. Cardona Peretó, F. and Freibert, A., 'The European Administrative Space and Sigma Assessments of EU Candidate Countries', 2007, Croatian Public Administration, vol. 7, no. 1, pp. 51-59.

7. CCPA, Croatian and Comparative Public Administration (previously Croatian Public Administration), Hrvatska i komparativna javna uprava, [Online] available at http:// www.iju.hr/HJU/o_casopisu.html (official webpage).

8. Charter of Fundamental Rights of the European Union, published in the Official Journal of the European Union, 2012/C 326/02 from 26.10.2012. 
9. Cheng, J.Y.S. and Lu, L.Q., 'Public Administration Research Issues in China: Evidence from Content Analysis of Leading Chinese Public Administration Journals', 2009, Issues E Studies, vol. 45, no. 1, pp. 203-241.

10. D'Orta, C., 'What Future for the European Administrative Space', Working Paper No. 2003/W/5, Maastricht: EIPA, 2003.

11. Dunn, N.W., Staronova, K. and Pushkarev, S. (eds.), Implementation: The Missing Link in Public Administration Reform in Central and Eastern Europe, Bratislava: NISPAcee, 2006.

12. European Ombudsman, 'The European Code of Good Administrative Behaviour', [Online] available at https://www.ombudsman.europa.eu/en/resources/code.faces\#/ page/1, accessed on September 16, 2016.

13. Henderson, A.C. and Terry, L.D. 'Unpacking the Global Perspective: Examining NISPAcee Region-Focused Public Administration Research in American Scholarly Journals', 2014, International Journal of Public Administration, vol. 37, no. 6, pp. 353-362.

14. Hofmann, H.C.H., 'Mapping the European Administrative Space', 2008, West European Politics, vol. 31, no. 4, pp. 662-676.

15. IPAR, International Public Administration Review (previously Administration), Mednarodna revija za javno upravo, [Online] available at http://www.fu.uni-lj.si/ zalozba/mednarodna-revija-za-javno-upravo/ (official webpage).

16. Koprić, I., 'Contemporary Croatian Public Administration on the Reform Waves', 2011, Yearbook of the Croatian Academy of Legal Sciences, vol. 2, no. 1, pp. 1-39.

17. Koprić, I., Marčetić, G., Musa, A., Đulabić, V. and Lalić Novak, G., Upravna znanost - Javna uprava u suvremenom europskom kontekstu (Administrative Science: Public Administration in the Contemporary European Context), Zagreb: Institute of Public Administration, 2014.

18. Koprić, I., Musa, A. and Lalić Novak, G., Europski upravni proctor (European Administrative Space), Zagreb: Institute of Public Administration, 2012.

19. Kovač, P. and Jukić, T., 'Development of Public Administration and its Research in Slovenia through the Lenses of Content Analysis of the International Public Administration Review', 2016, International Public Administration Review, vol. 14, no. 1, pp. 75-114.

20. Kovač, P., 'Developing New Governance Models and Administrative Practices in Central and Eastern Europe', in Kovač, P. and Gajduschek, G. (eds.), Contemporary Governance Models and Practices in Central and Eastern Europe: Selected Revised Papers from the $22^{\text {nd }}$ NISPAcee Annual Conference, (held in May 22-24, 2014, Budapest, Hungary), Bratislava: NISPAcee, 2015, pp. 7-18.

21. Kovač, P., 'Evropski upravni prostor - realnost ali mit' (European administrative space - reality or myth), 2003, Administration, vol. 1, no. 2, pp. 16-33.

22. Kovač, P., 'Slovene Administrative Reforms: At the Cross-Section of Post-Socialism, Legalism and Good Administration', in Vintar, M., Rosenbaum, A., Jenei, G. and Drechsler, W. (eds.), The Past, Present and the Future of Public Administration in Central and Eastern Europe, Bratislava: NISPAcee, 2013, pp. 152-177.

23. Lee, G., Benoit-Bryan, J. and Johnson, T.P., 'Survey Methods in Public Administration Research: A Content Analysis of Journal Publications', Conference Paper, $10^{\text {th }}$ National Public Management Research Conference, October 1-3, 2009, Ohio State University, Columbus. 
24. Lopižić, I., 'Usporedba zastupljenosti tema u znanstvenim časopisima o javnoj upravi' (Comparative Representation of Topics in Scientific Journals on Public Administration), 2013, Croatian and Comparative Public Administration, vol. 13, no. 2, pp. 399-431.

25. Mathis, K., 'Cultures of Administrative Law in Europe: From Weberian Bureaucracy to 'Law and Economics', in Helleringer, G. and Purnhagen, K. (eds.), Towards a European Legal Culture, Baden-Baden: Nomos, München: Beck, Oxford: Hart, 2014, pp. 139-162.

26. Noordegraaf, M., Brandsen, T. and Huitema, D., 'Fragmented but Forceful: Dutch Administrative Sciences and Their Institutional Evolution', 2006, Public Administration, vol. 84, no. 4, pp. 989-1006.

27. OECD, 'European Principles for Public Administration', 1999, SIGMA Papers, no. 27, Paris: OECD.

28. OECD, 'Preparing Public Administrations for the European Administrative Space', 1998, SIGMA Papers, no. 23, Paris: OECD.

29. OECD/SIGMA, 'The Principles of Public Administration', Paris: OECD, 2014.

30. Olsen, J.P., 'Towards a European Administrative Space', 2003, Journal of European Public Policy, vol. 10, no. 4, pp. 506-531.

31. Perry, J.L. and Kraemer, K.L., 'Research Methodology in the Public Administration Review 1975-1984', 1986, Public Administration Review, vol. 46, no. 3, pp. 215-226.

32. Peters, B.G. and Pierre, J. (eds.), Handbook of Public Administration, London: Sage, 2003.

33. Pusić, E., Nauka o upravi (The Science of Administration), Zagreb: Školska knjiga, 2002.

34. Raadschelders, J.C.N., Public Administration: The Interdisciplinary Study of Government, Oxford: Oxford University Press, 2011.

35. Schimmelfennig, F. and Sedelmeier, U. (eds.), The Europeanization of Central and Eastern Europe, Ithaca, USA: Cornell University Press, 2005.

36. Schuppert, G.F., Verwaltungswissenschaft, Baden-Baden: Nomos, 2000.

37. Statskontoret (The Swedish Agency for Public Management), 'Principles of Good Administration in the Member States of the European Union', Stockholm: Statskontoret, 2005, [Online] available at http://www.statskontoret.se/globalassets/publikationer/2000-2005-english/200504.pdf, accessed on January 15, 2017.

38. Terry, L.D., 'Reflections and Assessment: Public Administration Review 2000-2005', 2005, Public Administration Review, vol. 65, no. 6, pp. 643-645.

39. Trondal, J. and Peters, B.G., 'The Rise of European Administrative Space: Lessons Learned', 2013, Journal of European Public Policy, vol. 20, no. 2, pp. 295-307.

40. Tung-Wen Sun, M. and Yu-Wen Lin, J., 'Public Administration Research in Taiwan: A Content Analysis of Journal Articles (1990-2010)', 2013, The American Review of Public Administration, vol. 44, no. 2, pp.187-202.

41. Vintar, M., Rosenbaum, A., Jenei, G. and Drechsler, W. (eds.), The Past, Present and the Future of Public Administration in Central and Eastern Europe, Bratislava: NISPAcee, 2013.

42. Walker, R.W., Brewer, G.A. and Choi, Y., 'Public Administration Research in East and Southeast Asia: A Review of the English Language Evidence, 1999-2009', 2014, The American Review of Public Administration, vol. 44, no. 2, pp. 131-150. 


\section{Appendix: Coding scheme of content analysis in EAS research}

\section{Paper ID}

2. Journal title: the IPAR/MRJU or the CCPA/HKJU

3. Year of publication: 2011, 2012, 2013, 2014

4. Paper title (in language published and/or ENG)

5. Typology (according to Slovenian/Cobiss categorization)

6. Language: 1 - SVN; 2 - ENG; 3 -SVN and ENG; 4 - HRV; 5 - DEU; 6 - SVN in the CCPA

7. $1^{\text {st }}-5^{\text {th }}$ author's name

8. $1^{\text {st }}-5^{\text {th }}$ author's country (alpha-3 code of the ISO standard)

9. $1^{\text {st }}-5^{\text {th }}$ author's institution - Name

$10.1^{\text {st }}-5^{\text {th }}$ author's institution - Type 1 - University - local/domestic (from the same country as the issuer); 2 - University - foreign; 3 - Research institute (if autonomous, otherwise under 1 or 2); 4 - Associations, NGOs; 5 - Public sector (administrative authorities, municipalities, agencies, courts); 6 - International organization (e.g., OECD); 7 - Other (enterprises, pensioners, students)

11.Nature of collaboration (if more than one author): 1 - Faculty/research institute and faculty/research institute $=$ same organization; $2-$ Faculty/research institute and faculty/research institute $=$ different organizations; $3-$ Faculty (professor) and graduate/student; 4 - Faculty and public sector/civil servant or NGO; 5 - Faculty/ research institute and international organization; 6 - Other (e.g., faculty and private organization)

12.International collaboration between/among co-authors: 1 - Yes; 2 - No

13. Geographical focus of the paper; Is the paper focused on a specific country?: 1-Yes, on one country; 2 - Yes, on two or more countries (comparatively); 3 - Yes, on one or more countries and the EU; 4 - No

14. Geographical focus of the paper (IF 33=1-3, which country or EU/region (e.g., SEE)) 15.First dominant discipline: 1 - Law; 2 - Economics; 3 - Management (with organization, HRM, TQM, etc.); 4 - Politology/policy analysis and/or sociology; 5 - Informatics; 6 - Individual fields/interdisciplinary elaboration (e.g., education, environment, social care, etc.)

16.Second dominant discipline (optional) (1-6)

17.First dominant topical orientation

1 - Human rights

2 - Regulation of PA, Better Regulation, administrative barriers, etc.

3 - Transparency, openness, participation, civil society inclusion

4 - Organization in PA, state organs, decentralization, agencies

5 - Regionalism and local self-government

6 - HRM, civil service, ethics, integrity, culture

7 - Public finances, budget, taxes

8 - E-government

9 - TQM, quality, NPM, good governance 
10 - Privatization, public services/concessions

11 - Processes, administrative procedures and acts, legal/managerial good administration

12 - Individual public / PA policies (education, environment, customs, etc.)

13 - PA / PS (general) reform/s

14 - PA discipline / administrative science

18. Second dominant topical orientation (1-14)

19.Elements of Europeanization in topic: 1 - Yes; 2 - No; 3 - specifically EAS

20.Comparative research: 1 - Yes, comparison among countries or regions; 2 - Yes, country/ies vs. EU; 3 - Yes, comparison among organizations; 4 - Yes, time-based comparison; 5 - No 